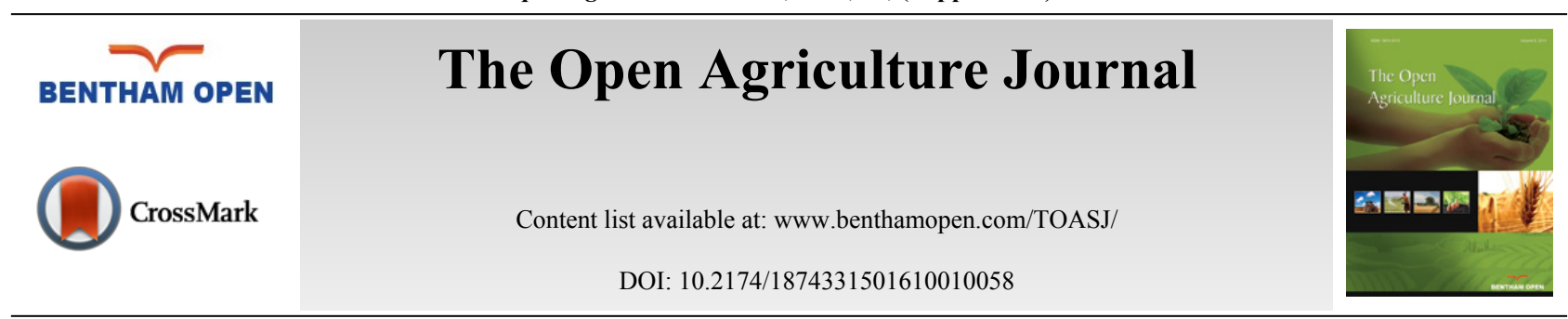

REVIEW ARTICLE

\title{
Functional Food to Regulate Satiety and Energy Intake in Human
}

\author{
Marcela Alviña ${ }^{1, *}$ and Hector Araya ${ }^{1,2}$ \\ ${ }^{I}$ Departamento de Nutrición y Alimentos, Facultad de Farmacia, Universidad de Valparaíso, Valparaiso, Chile \\ ${ }^{2}$ University of Chile, Faculty of Medicine, Human Nutrition Center, Santiago, Chile
}

Received: December 4, 2015

Revised: August 1, 2016

Accepted: August 4, 2016

\begin{abstract}
Nowadays obesity is affecting people from all socioeconomic levels in most of the countries worldwide. Appetite and satiety are complex processes which influence the energy regulation. As a solution to enable individuals to control their body weight, functional foods were developed in order to reduce the energy intake. However, the methodology to assess the satiating efficiency of functional foods, including monitoring through biomarkers, is very complex and needs to be standardized. The aim of the present work was to analyse the results published in the area of functional food and satiety to demonstrate the potential satiating role of these foods.
\end{abstract}

Keywords: Functional food, Healthy ingredients, Intake regulation, Satiety determination, Satiety biomarkers.

\section{INTRODUCTION}

Nowadays, the research on the regulation of food intake in human is on the rise, considered as the main focus to understand a possible cause of the high prevalence of obesity and non-transmissible chronic diseases in the global population. A great number of countries showed obesity prevalence higher than $10 \%[1,2]$ and it is evident that the prognostic is not promissory for the obesity and other chronic diseases associated with obesity $[3,4]$. The actual life style, characterized by the consumption of high energy density foods and a low level of physical activity in several populations, is the main cause of these health problems. The main result of this obesogenic behavior is a positive energy balance which represents the basis of the major prevalence of overweight and obesity. Furthermore in several studies, conducted on low income families, the consumption of high carbohydrates and low dietary fiber diet was demonstrated $[5,6]$. This kind of diet, determines a rapid enzymatic digestion, increasing glycemia levels and inducing a low satiety $[7,8]$. At the same time the low amount of dietary fiber is associated with a poor weight management $[9,10]$. A possible dietary solution to control the obesity rate is to recommend the intake of common foods with high satiety potential. In the last years functional foods which include ingredients with a high potential to produce a strong feeling of fullness were developed. The efficacy of these foods must be evaluated by clinical trials performed in humans and accepted by regulatory organisms (Halford Jc, 2012). The importance of these foods in the actual population feeding is essential to control the energy regulation process. This latter regulation is based on complex biological events between the peripheral gastrointestinal tissues and the central nervous system, which integrates the information and controls the process. Also the energy regulation is affected by the environmental factors [11]. For these reasons, the methodological designs and the procedures applied to study the efficacy of functional foods in the energy intake regulation, represent essential factors for industrial, consumer and scientist sectors. The aim of the present work was to analyse the results published in the area of food and satiety to demonstrate the potential satiating food. This information is valuable to provide a background for the discussion of conceptual and practical alternatives considered in the development of functional foods.

\footnotetext{
* Address correspondence to this author at the Departamento de Nutrición y Alimentos, Facultad de Farmacia, Universidad de Valparaíso. Av Gran Bretaña 1093, Valparaíso, Chile; Tel: 56032 2508147; E-mail: marcela.alvina@uv.cl
} 


\section{Energy Intake Regulation}

The models proposed to study the regulation of energy intake indicate that food intake starts with external signals related to their metabolism (Fig. 1). The food intake begins when glycaemia falls and plasma fatty acid concentration increases [12], as demonstrated by Campfield and co-workers which found, in their study conducted on rat, that food intake starts when glycaemia falls near $12 \%$ [13]. On the other side, the increment of satiety is due to an elevation of plasma cholecystokinin (CCK) and insulin in the central nervous system. Both biomarkers are associated to the surfeit condition [14]. During the consumption phase, food intake is controlled by orosensoriales, cognitive and postingestive effects $[15,16]$. Term phase is led primarily by the food volume in the stomach and by the chemical composition in the small intestine [17 - 19]. The food frequency consumption is another important factor in the food intake regulation, because it is highly related to the cell energy status. The feeding frequency increases when cells are in energy deficit [20]. From a physiological perspective, the biochemical reactions originate signals captured by the central nervous system, leading to the sensation of appetite or fullness recognized by the subjects. However, the selection of foods and the amount of energy consumed by individuals are strongly conditioned by dietary factors. For example, the culinary processes and the palatability are involved in energy regulation [21]. In addition it is well established that other nutritional variables such as energy density, macronutrient content and variety of foods offered during a meal time, can modulate energy intake [22 - 24].

\section{FEEDING PHASE}

\begin{tabular}{|c|c|c|c|}
\hline & INITIAL & CONSUMPTION & TERM \\
\hline $\begin{array}{l}\text { Internal } \\
\text { stimulus } \\
\text { related to } \\
\text { metabolism }\end{array}$ & $\begin{array}{l}\text { Slight drop in plasma } \\
\text { glucose } \\
\text { Increase fatty acid } \\
\text { levels }\end{array}$ & & $\begin{array}{l}\text { Increase CCK levels } \\
\text { Increase Insulin levels }\end{array}$ \\
\hline $\begin{array}{l}\text { Food } \\
\text { related } \\
\text { Stimulus }\end{array}$ & & $\begin{array}{l}\text { Effects: } \\
\text { Orosensorieles } \\
\text { Cognitive } \\
\text { Postingestive }\end{array}$ & $\begin{array}{l}\text { Volume in the stomach } \\
\text { Chemical composition } \\
\text { in the small intestine }\end{array}$ \\
\hline
\end{tabular}

Fig. (1). Model intake regulation.

The terms more used to identify the different biological state that express the energy regulation are appetite, satiation and satiety. Appetite can be defined as the internal state that produces a strong motivation to eat when foods are available. Once the individuals eat, some signals influence the ending of the feeding, giving a feeling of fullness and satiation $[25,26]$. Each meal is followed by a variable time period characterized by the absence of hunger, defined as a state of repletion of energy that occurs after a meal [27]. The length of inter-meal period is known as satiating efficiency which is specific for each food or their combinations $[28,29]$. The intake of foods with elevated satiety efficiency also decreases the number of eating episodes during the day, thus reducing food and energy intakes [30, 31]. The sequence of events shown in Fig. (1), explain the neural and hormonal responses in anabolic or catabolic pathways determining the energy balance and body weight changes [14, 32, 33]. Furthermore, the food intake regulation is influenced by multiple factors beside the biological factors such as psychological, socio demographic, cultural and individual factors $[11,34]$. 


\section{Methodology to Obtain Healthy Functional Foods to Regulate Energy Intake}

The methodology approach applied in most of the researches on appetite and satiety is varied and complex because of the numerous variables involved $[31,35,36]$. Consequently, the results obtained from these studies are related with the experimental design applied and the derived conclusions have to be carefully interpreted. The methodologies used in most of the reviewed studies for the development and evaluation of functional foods, designed to increase satiety, are divided into three stages (Fig. 2). The first stage corresponds to "intervention activities" and consists mainly in the addition of bioactive compounds into the food matrix to obtain a new food that can be able of producing satiety and body weight regulation. At this stage it is necessary to define the functional ingredient, the dose and the selected vehicle food. The second stage corresponds to the evaluation of technological processes applied to obtain a functional food ready to be developed industrially. At this stage, it is necessary to handle technological functionality of the food to achieve high acceptability and sensory characteristics. The third stage is the application of a clinical methodology to evaluate the satiety potential of the functional food through various experimental designs.

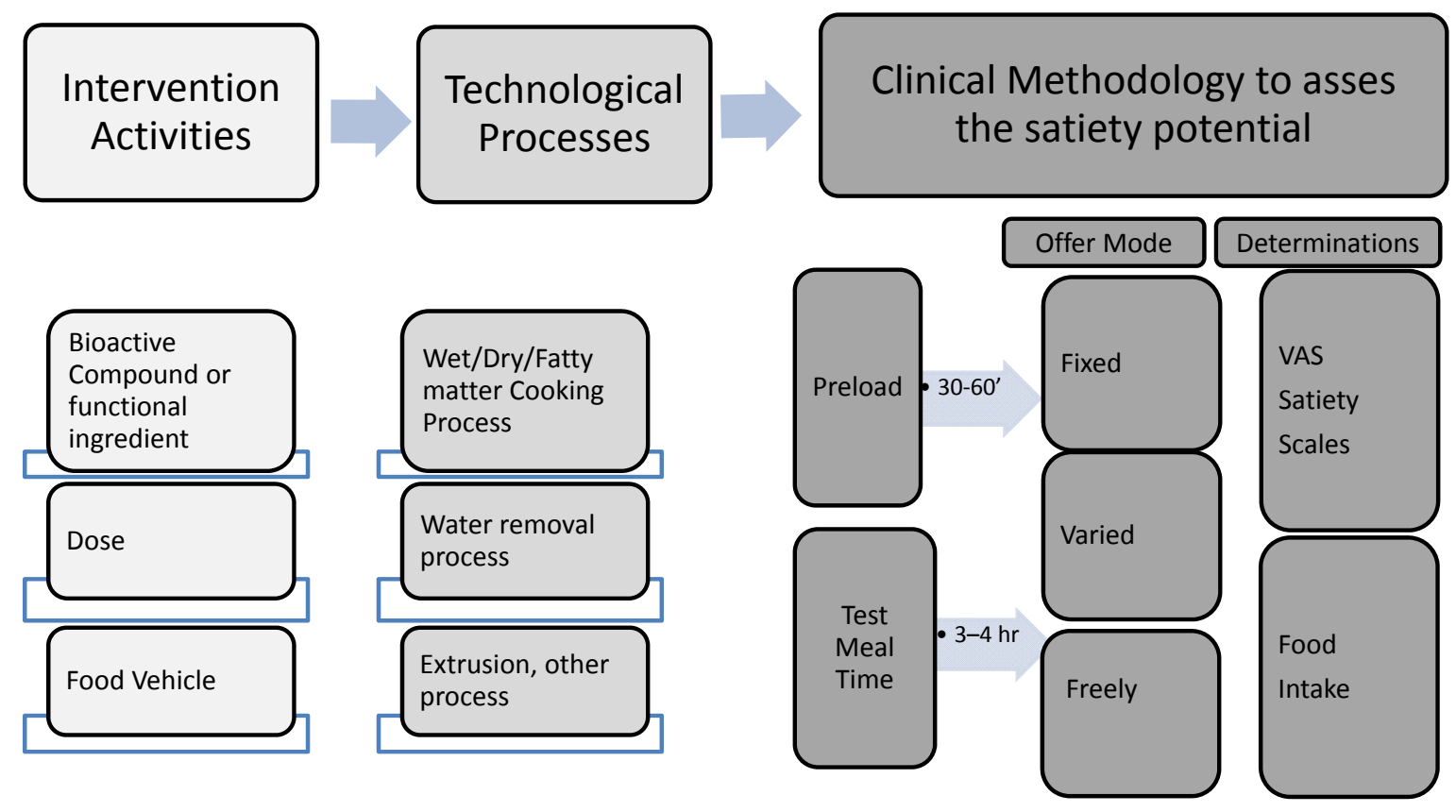

Fig. (2). Experimental design to develop and assess the efficacy of functional foods in satiation and satiety. The acronym VAS stand for Visual Analogue Scale.

One of the designs most frequently used to evaluate a short term satiety consists of the assignment of a preload test where subjects have to consume the whole of a small portion (100-150 g) [36]. After a brief period of time (30 or 60 minutes) the amount of food that subjects are able to eat is measured or the perception of satiety assessed using the Visual Analogue Scale (VAS) [37, 38]. This method is used to determine the short-term satiety: the participants are asked to specify their sensations of hunger, satiety, fullness, and desire to eat in a particular features, using this scale of values from 0 to 10 centimeters [39 - 41]. It is advisable to use the VAS before starting the trial, immediately before and after the consumption of the test food and at 15-30-60-90-120 minutes, to compare the results with the measurements of plasmatic biomarkers, such as glycemic response.

Another experimental design to assess the satiety potential of the functional food is to include it in a meal time, such as breakfast or lunch. After 3 hours, the satiety was evaluated determining the subsequent intake or using VAS [36]. In both designs, preload or meal time, foods are supplied in pre-weighed portions beyond the energy requirement of the subjects. Three ways to provide food are available: fixed, varied or freely. In the first case, a unique preparation in an amount greater than normally consumed are offered, with the possibility to give more to the subjects if requested. In the varied offer mode, 5 or 6 foods with different nutritional and orosensorial characteristics, such as a salad, a stew, a glass of juice or drink, a piece of bread, a serving of fruit and milk dessert are offered. Other authors prefer to use different types of sandwiches accompanied by portions of fruit and liquid foods. In the freely offer mode, the food is served on a table and the subjects could take as much as they liked. In this design a lot of small portions of several foods are 
offered, taking care to strike a balance between different sensory characteristics of sweet and savory foods, liquids, gels and solids foods, meat and vegetables, dairy products and baked goods. Total food intake is determined by differential weighing which compares the amount of foods offered and the amount left over by each subject [35]. There are many studies that only measure satiety by the VAS without the determination of the food intake in the subsequent meal. The three methodological stages described in the Fig. (2) can be applied to elaborate functional foods in the area of the regulation of energy intake. Nevertheless, in each stage it is important to constantly create a valuable feedback for the optimization of the whole process.

\section{Methodological Design Considerations}

In each stage of the experimental design it is necessary to take into account a large number of variables. For example, in the intervention stage it is necessary to essay different doses of the bioactive compound to obtain an adequate satiation and satiety potential and a good sensorial and technological quality in the functional food. The scientific literature shows that for the same bioactive compounds, clinical studies use different doses. Thus, there are studies that essayed elevated doses to assure the beneficial effect of the compound and others studies are interested in essaying a minor dose which can be found in normal food portions. It is necessary to control also the amount and the type of macronutrients, dietary fiber, phytochemical and other food compounds that could affect satiety and accompany functional ingredient studied. On the other hand, technological and culinary treatments influence satiating efficiency of foods. For example, the gelatinization of starches in cooking water drastically reduces their satiating effect [7, 42]. Additionally, physiochemical changes in food matrix such as texture, viscosity and consistency are detected when foods are industrially or culinary treated $[43,44]$. Moreover, the sensorial characteristics of foods can also affect their ability to produce satiety. Some authors showed a correlation between brain activity in the regions that control food intake and the rate of pleasantness [45 - 47]. Consequently, the nutritional, sensorial and physiochemical characteristics of food must be paired or controlled and the results published frequently did not show an adequate control of the experimental variables. The various ways to offer food are appropriate for different: the fixed supply is suitable for subjects with small gastric capacity, like preschool children. Instead, offering varied or freely designs are more appropriate for adolescent and adults. In these latter two, the concept of sensory-specific satiety is used; it means that the subjects can obtain satiety for one type of feed, still maintaining an appetite for foods with different characteristics [48 - 50]. The variety of textures, tastes, smells and colors is also involved in this phenomenon [16, 33, 51]. During a meal, the absence of varied choice tends to limit food intake, whereas variety tends to promote eating. Therefore, in this design it is very important to get a good balance between the physiochemical, sensory and nutritional characteristics of food offered. In this way, subjects can express their real potential capacity to consume. Regardless, the three ways to offer food (fixed, varied or freely) should all include foods with high acceptability by the subjects involved in the study. Another important aspect to evaluate the satiating potential of a functional food or ingredient is to standardize the hunger level of each subject, regulating the fasting condition of the previous days. The time between the ingestion of functional food and the measurement of satiety change, basing on the purpose of the study. If the aim is to evaluate the effect of the oro-sensorial and gastrointestinal factors on satiety, the delay should be no more than 30 minutes, while if the purpose is to investigate the inhibitory effects post-absorptive, the delay must be longer.

The review of published studies shows that there are two methods used for satiety measurement. The first evaluates the perception of satiety reported by the participants and the second measures the actual food intake. Therefore, the VAS provides a subjective evaluation of satiety while the measurement of actual food intake provides an objective assessment. Both methods are widely accepted in satiety assessment and can be considered as markers to evaluate the direct effects of food intake [38]. Some variables that must be considered during a study are the environmental conditions in which results are obtained. The laboratory conditions are more appropriate to have an adequate control of the different variables while the free-living conditions are similar to the normal way of eating of the subjects. When the objective of the study is to obtain physiological responses or to study the conceptual framework of some biomarkers, the research must be carried out in a laboratory context. On the contrary, if the aim of the investigation is to determine the effect of food on body weight changes which requires a long period of time, it is more appropriate to perform the measurements in a free-living environment. In both approaches the environmental conditions need to be considered in the interpretation of the results and in their projection to the feeding of the individuals.

\section{Metabolic Biomarkers Related to Satiety}

The experimental researches in the field of energy regulation need to study different compounds derived from the metabolism of macronutrient or peptides in the cells, acting as messengers from the gastrointestinal tract to the central 
nervous system, principally in certain regions of the hypothalamus. These biomarkers help to understand how the processes of satiety and appetite are modified by the dietary components, contributing to reach an optimum in the usefulness of the functional ingredients designed to increase satiety. The metabolic biomarkers are simultaneously determined with the measurement of satiety. These biomarkers may provide valuable information to explain the conceptual basis to understand the effect of dietary bioactive compounds on human cells. Some researchers recommend the determination of Cholecystokinin (CCK) and Glucagon-Like Peptide-1 (GLP1) as markers of satiation and the measure of glycaemia, insulinemia, Gastric Inhibitory Polypeptide (GIP) and Peptide YY (PYY) as biomarkers of satiety [52]. Ghrelin is an excellent marker of satiety, which acts on hypothalamus receptors as a peripheral hormone, stimulating the expression of neuropeptide $\mathrm{Y}$ and agouti-related protein [53]. The ghrelin's relation with hunger responses and food intake is well established [54 - 56]. In a study conducted by Batterham and co-workers the role of PYY on satiety was assessed. The research demonstrated that PYY is a biomarker of satiety acting as a peripheral signal on central nervous system receptors [57].

Carbohydrates are the nutrients mainly consumed in the diet and consequently they are important in the regulation of energy intake, to have biomarkers able to predict the effect of carbohydrate intakes on satiety. Postprandial glucose and insulin levels depend on the available amounts of carbohydrates and on their digestion rate. If during the digestion, the carbohydrates are rapidly absorbed, the glycemic response is rapid and when an accentuate fall is produced, a higher energy intake was proven $[58,59]$. Consequently sharp curves are associated with hunger and flat curves are associated with satiety [60, 61]. Furthermore, high glycemic response increases the risk of obesity, diabetes, cancer and cardiovascular disease [62]. Some investigators suggested that insulinemia is a more sensible biomarker than glycemic $[63,64]$. The cereals and their products presented extremely different glycemic responses and in the low zones oat (Avena sativa) and the pasta cooked "al dente", that is cooked to be firm to the bite are located [65, 66]. On the other hand, white bread determines the increase of blood glucose which can be explained with the high concentration of starches with rapid digestion rate [67, 68].

Biomarkers for proteins are the levels of amino acid in plasma which are related to the release of hormones and peptides connected with the central nervous system [69]. The oxidation process of amino acids, that starts in the liver and facilitates ATP synthesis, is directly related with the protein concentration in foods consumed: this suggests that in order to obtain a potential rise of satiety, it's necessary to consume a high amount of dietary proteins in one meal per day $[70,71]$.

There are a considerable number of researches on metabolic biomarkers and their relationship with appetite and satiety in humans. However, their use in the assessment of food satiety efficiencies or in the contribution on the design and the evaluation of functional foods, are not completely accepted because the evidences are limited and controversial. The plasma levels of glucose and insulin are the more considered biomarkers used as valuable information to connect the theory with the practical actions in the area of functional foods. The analysis of the literature revised suggests that the majority of the experimental designs are carried out in a short period of time either in the same meal time (satiation) or in the subsequent meal time (satiety). These studies are planned to evaluate the physiological processes of appetite, satiety and satiation but they were not designed to evaluate the energy intake in the long term where it is possible to evaluate the changes in bodyweight. The validity of the metabolic biomarkers in the field of appetite and satiety is a key point to have an approximation of conceptual framework to explain how the cells respond to the metabolic and biochemical challenges induced by food intake and to give an answer to the question "why we eat the energy and foods that we eat?"

\section{Most Promising Functional Foods to Increase Satiety According to Scientific Knowledge}

A great proportion of functional foods for energy regulation is based on the addition of isolated soluble fiber (i.e. $\beta$ glucans) to the food matrices or the inclusion of foods rich in soluble fiber such as oats and barley (Hordeum vulgare L.). Most of the health benefits associated with high viscosity foods are due to $\beta$-glucans, which demonstrated some physiological effects such as the satiety and the moderation of the glycemic and insulinemic postprandial response [37, 72, 73]. To understand if the $\beta$-glucans benefits are dose-dependent, several studies were conducted to define the lowest dose which demonstrated the effect above mentioned. The incorporation of oat $\beta$-glucans (from $2.5 \mathrm{~g}$ to $5 \mathrm{~g}$ ) into beverages with different energy contents, showed a higher perception of satiety compared to control food, but a doseresponse relationship was not observed. Moreover, the oat had a high viscosity which produced the increased perception of satiety [74]. In the same way Beck et al, showed that a lower dose of oat $\beta$-glucan (2.2 g) was able to increase subjective satiety while an higher dose of $5 \mathrm{~g}$ of $\beta$-glucans reduced energy intake by more than $400 \mathrm{~kJ}$ in the subsequent 
meal [75]. The effect of foods combined with $\beta$-glucans in the population must be taken into account for the submission of healthy messages. Few studies linked the recurrent intake of oat $\beta$-glucans with the reduction of body weight. During a research of Beck et al., fourteen overweight subjects (balanced by gender) were followed for 3 months with an energy restricted diets with different level of $\beta$-glucans. The use of the soluble fibre in food could be related to the weight loss and appetite control [76].

The literature revised in this paper showed that in short time and in laboratory conditions the addition of oat $\beta$ gucans are beneficial to increase satiety and to decrease the glycemic and the insulinemic responses. Barley is another cereal investigated as source of soluble dietary fibre with healthy benefices [77 - 80]. Crackers and cookies enriched with $3.5 \mathrm{~g}$ of barley $\beta$-glucans showed positive responses in the insulinemic response [81]. As demonstrated by Vitaglione et al., this soluble fibre may be also incorporated into snack products such as biscuits, determining a decrease in appetite sensation [82]. In some researches some functional ingredients were incorporated into the white wheat bread with the aim to test the glycaemic and insulinemic responses and to evaluate the satiety capacity of the bread $[83,84]$. In the study, Liljeberg showed that a bread with $80 \%$ barley produced a glycaemic index of 33 while the control bread presented a glycaemic index of 69 [83]. In the same way, Hallström found that bread products based on a novel wheat genotype with elevated amylose content (38\%) induced significant lower postprandial glucose response [84].

Others wheat products such as pastes were also used as vehicles to add healthy ingredients such as soluble and insoluble fibres: $\beta$ - glucans, resistant starches, FOS [85 - 88]. It is well established that proteins are the macronutrient that causes the greater satiety in the short-term $[69,89]$. However, most of the studies were experimental designs which used protein concentrations at $45-50 \%$ of the total energy intake [71, 90]. Long-term studies are less conclusive and used diets providing $25-45 \%$ of energy from protein [91]. These results were applied to functional foods based on protein isolated such as casein, whey and soy protein [92, 93]. Actually, the research in this area is based on the effect of different food proteins types beyond their protein concentration [94]. This is the case of milk proteins such as casein and whey. The results demonstrated that both compounds increase satiety but with diverse efficiency. Casein presents a more rapid digestion in upper gastrointestinal zones and its metabolic action appears in a short postprandial time [95]. On the contrary, whey protein shows a more slow digestion and its metabolic role can be expressed in a longer time [96, 97] demonstrated that the whey proteins are more potent than casein in the increase of CCK and GLP 1 and in the decrease of appetite. Today, an important research area is to formulate and evaluate functional foods based on the combination of protein with soluble fiber with the purpose to obtain a synergism to have a product with a high satiating potential.

The experimental research on food intake and satiety is very important, in order to design, develop and evaluate the role of functional foods on population's health. The primary aim is low energy intake and maintaining body weight of individuals at the risk of obesity. Foods need to be carefully evaluated considering food chemical composition, the structure and the physical properties of the food matrix, processing conditions, the amount of the satiating ingredients and their interactions with the others food components. When these foods meet the requirements of the food regulation of each country, they can be incorporated in the market system in varied forms [98], facilitating the consumers purchase and representing a dietary tool to alleviate the epidemic of obesity in the whole world.

\section{CONCLUSION}

The present paper suggests some actions useful to obtain a better application of the different methodologies for the evaluation of the efficacy of functional foods in the increase of satiety. These actions are summarized in the following items:

- Development of studies to standardize the methodology for assessing appetite and satiety.

- Use of standard food used as controls to assure the validity of the methodologies.

- Work on the homologation of the health messages and nutrition labelling.

- Increase private and public budget to study the healthy characteristics of new ingredients added to functional foods.

- Increase the knowledge on the usefulness of biomarkers used in the design of functional foods.

- Provide scientific information about the use of functional foods to increase satiety and how they can be integrated in the diet of the consumers. 


\section{CONFLICT OF INTEREST}

The authors confirm that this article content has no conflict of interest.

\section{ACKNOWLEDGEMENTS}

Declared none.

\section{REFERENCES}

[1] James WP. The epidemiology of obesity: the size of the problem. J Intern Med 2008; 263(4): 336-52. [http://dx.doi.org/10.1111/j.1365-2796.2008.01922.x] [PMID: 18312311]

[2] Low S, Chin MC, Deurenberg-Yap M. Review on epidemic of obesity. Ann Acad Med Singapore 2009; $38(1): 57-9$. [PMID: 19221672]

[3] Diet, nutrition and the prevention of chronic diseases. Report of the joint WHO/FAO expert consultation WHO Technical Report Series, No. 916 (TRS 916), 2002.

[4] Misra A, Khurana L. Obesity and the metabolic syndrome in developing countries. J Clin Endocrinol Metab 2008; 93(11)(Suppl. 1): S9-30. [http://dx.doi.org/10.1210/jc.2008-1595] [PMID: 18987276]

[5] Peña M, Bacallao J. Obesity and Poverty: A new Public Helth Challenge. Washington, DC: PAHO 2000.

[6] Levine JA. Poverty and obesity in the U.S. Diabetes 2011; 60(11): 2667-8. [http://dx.doi.org/10.2337/db11-1118] [PMID: 22025771]

[7] Alviña M, Araya H. Rapid carbohydrate digestion rate produced lesser short-term satiety in obese preschool children. Eur J Clin Nutr 2004; 58(4): 637-42

[http://dx.doi.org/10.1038/sj.ejcn.1601859] [PMID: 15042132]

[8] Bazzano LA, Song Y, Bubes V, Good CK, Manson JE, Liu S. Dietary intake of whole and refined grain breakfast cereals and weight gain in men. Obes Res 2005; 13(11): 1952-60. [http://dx.doi.org/10.1038/oby.2005.240] [PMID: 16339127]

[9] Koh-Banerjee P, Franz M, Sampson L, et al. Changes in whole-grain, bran, and cereal fiber consumption in relation to 8-y weight gain among men. Am J Clin Nutr 2004; 80(5): 1237-45. [PMID: 15531671]

[10] Harland JI, Garton LE. Whole-grain intake as a marker of healthy body weight and adiposity. Public Health Nutr 2008; $11(6)$ : 554-63. [http://dx.doi.org/10.1017/S1368980007001279] [PMID: 18005489]

[11] Wansink B. Environmental factors that increase the food intake and consumption volume of unknowing consumers. Annu Rev Nutr 2004; 24: 455-79.

[http://dx.doi.org/10.1146/annurev.nutr.24.012003.132140] [PMID: 15189128]

[12] Aronoff SL, Berkowitz K, Shreiner B, Want L. Glucose metabolism and regulation: beyond insulin and glucagon. Diabetes Spectr 2004; 17: 183-90. [http://dx.doi.org/10.2337/diaspect.17.3.183]

[13] Campfield LA, Brandon P, Smith FJ. On-line continuous measurement of blood glucose and meal pattern in free-feeding rats: the role of glucose in meal initiation. Brain Res Bull 1985; 14(6): 605-16. [http://dx.doi.org/10.1016/0361-9230(85)90110-8] [PMID: 4027699]

[14] Delzenne N, Blundell J, Brouns F, et al. Gastrointestinal targets of appetite regulation in humans. Obes Rev 2010; 11(3): 234-50. [http://dx.doi.org/10.1111/j.1467-789X.2009.00707.x] [PMID: 20433660]

[15] Blundell JE, Rogers PJ, Hill AJ. Evaluating the Satiating power of foods: implications for acceptance and consumption. London: Academic Press 1988 .

[16] de Graaf C. Texture and satiation: the role of oro-sensory exposure time. Physiol Behav 2012; 107(4): 496-501. [http://dx.doi.org/10.1016/j.physbeh.2012.05.008] [PMID: 22609070]

[17] Oesch S, Rüegg C, Fischer B, Degen L, Beglinger C. Effect of gastric distension prior to eating on food intake and feelings of satiety in humans. Physiol Behav 2006; 87(5): 903-10. [http://dx.doi.org/10.1016/j.physbeh.2006.02.003] [PMID: 16549077]

[18] Powley TL, Phillips RJ. Gastric satiation is volumetric, intestinal satiation is nutritive. Physiol Behav 2004; 82(1): 69-74. [http://dx.doi.org/10.1016/j.physbeh.2004.04.037] [PMID: 15234593]

[19] Cummings DE, Overduin J. Gastrointestinal regulation of food intake. J Clin Invest 2007; 117(1): 13-23. [http://dx.doi.org/10.1172/JCI30227] [PMID: 17200702]

[20] Seeley RJ, Woods SC. Monitoring of stored and available fuel by the CNS: implications for obesity. Nat Rev Neurosci 2003; 4(11): 901-9. [http://dx.doi.org/10.1038/nrn1245] [PMID: 14595401]

[21] Stroebe W, Papies EK, Aarts H. From homeostatic to hedonic theories of eating: self-regulatory failure in food-rich environments. Appl Psychol 2008; 57: 172-93. 
[http://dx.doi.org/10.1111/j.1464-0597.2008.00360.x]

[22] Anderson GH, Aziz A, Abou Samra R. Physiology of food intake regulation: interaction with dietary components. Nestle Nutr Workshop Ser Pediatr Program 2006; 58: 133-43. [PMID: 16902331]

[23] Araya H, Vera G, Alviña M. Effect of the energy density and volume of high carbohydrate meals on short term satiety in preschool children. Eur J Clin Nutr 1999; 53(4): 273-6.

[http://dx.doi.org/10.1038/sj.ejcn.1600721] [PMID: 10334652]

[24] Rolls BJ, Hetherington M. The role of variety in eating and body weight regulation. Sussex, England: John Wiley \& Sons 1989.

[25] Blundell JE, Burley VJ. Satiation, satiety and the actions of fibre of food intake. Int J Obes 1987; 11(1): 9-25. [PMID: 3032819]

[26] Van Itallie TB, Vanderweele DA. The phenomenon of satiety. London: Libbey 1981.

[27] Blundell JE. Hunger, appetite and satiety constructs in search of identities. London: Applied Science Publishers 1979; pp. $21-42$.

[28] Kissileff HR. Satiating efficiency and a strategy for conducting food loading experiments. Neurosci Biobehav Rev 1984; 8(1): 129-35. [http://dx.doi.org/10.1016/0149-7634(84)90028-9] [PMID: 6728356]

[29] Kissileff HR, Gruss LP, Thornton J, Jordan HA. The satiating efficiency of foods. Physiol Behav 1984; 32(2): 319-32. [http://dx.doi.org/10.1016/0031-9384(84)90147-1] [PMID: 6718557]

[30] Benelam B. Satiation, satiaty and their effects on eating behavior. Nutr Bull 2009; 34: 126-73. [http://dx.doi.org/10.1111/j.1467-3010.2009.01753.x]

[31] Blundell JE, de Graaf C, Finalyson G, et al. Measuring food intake, hunger, satiety, and satiation in the laboratory. $2^{\text {nd }}$ ed. SAGE Publications Inc 2009.

[32] Stefater MA, Seeley RJ. Central nervous system nutrient signaling: the regulation of energy balance and the future of dietary therapies. Annu Rev Nutr 2010; 30: 219-35. [http://dx.doi.org/10.1146/annurev.nutr.012809.104723] [PMID: 20225935]

[33] Smeets PA, Erkner A, de Graaf C. Cephalic phase responses and appetite. Nutr Rev 2010; 68(11): 643-55. [http://dx.doi.org/10.1111/j.1753-4887.2010.00334.x] [PMID: 20961295]

[34] Hill JO, Peters JC. Environmental contributions to the obesity epidemic. Science 1998; 280(5368): 1371-4. [http://dx.doi.org/10.1126/science.280.5368.1371] [PMID: 9603719]

[35] Blundell J, de Graaf C, Hulshof T, et al. Appetite control: methodological aspects of the evaluation of foods. Obes Rev 2010; 11(3): 251-70. [http://dx.doi.org/10.1111/j.1467-789X.2010.00714.x] [PMID: 20122136]

[36] Livingstone MB, Robson PJ, Welch RW, Burns AA, Burrow MS, McCormack C. Methodological issues in the assessment of satiety. Scand J Nutr 2000; 44: 98-103.

[37] Panahi S, Ezatagha A, Temelli F, Vasanthan T, Vuksan V. $\beta$-glucan from two sources of oat concentrates affect postprandial glycemia in relation to the level of viscosity. J Am Coll Nutr 2007; 26(6): 639-44. [http://dx.doi.org/10.1080/07315724.2007.10719641] [PMID: 18187427]

[38] Flint A, Raben A, Blundell JE, Astrup A. Reproducibility, power and validity of visual analogue scales in assessment of appetite sensations in single test meal studies. Int J Obes Relat Metab Disord 2000; 24(1): 38-48. [http://dx.doi.org/10.1038/sj.ijo.0801083] [PMID: 10702749]

[39] Cardello AV, Schutz HG, Lesher LL, Merrill E. Development and testing of a labeled magnitude scale of perceived satiety. Appetite 2005; 44(1): 1-13.

[http://dx.doi.org/10.1016/j.appet.2004.05.007] [PMID: 15604029]

[40] Stubbs RJ, Hughes DA, Johnstone AM, et al. The use of visual analogue scales to assess motivation to eat in human subjects: a review of their reliability and validity with an evaluation of new hand-held computerized systems for temporal tracking of appetite ratings. Br J Nutr 2000; 84(4): 405-15.

[http://dx.doi.org/10.1017/S0007114500001719] [PMID: 11103211]

[41] Shields BJ, Palermo TM, Powers JD, Grewe SD, Smith GA. Predictors of a child's ability to use a visual analogue scale. Child Care Health Dev 2003; 29(4): 281-90. [http://dx.doi.org/10.1046/j.1365-2214.2003.00343.x] [PMID: 12823333]

[42] Raben A, Tagliabue A, Christensen NJ, Madsen J, Holst JJ, Astrup A. Resistant starch: the effect on postprandial glycemia, hormonal response, and satiety. Am J Clin Nutr 1994; 60(4): 544-51. [PMID: 8092089]

[43] Alviña M, Araya H, Vera G, Pak N. Effect of starch intake on satiation and satiety in preschool children. Nutr Res 2000; 20 : 479-89. [http://dx.doi.org/10.1016/S0271-5317(00)00140-8]

[44] Tsuchiya A, Almiron-Roig E, Lluch A, Guyonnet D, Drewnowski A. Higher satiety ratings following yogurt consumption relative to fruit drink or dairy fruit drink. J Am Diet Assoc 2006; 106(4): 550-7. [http://dx.doi.org/10.1016/j.jada.2006.01.004] [PMID: 16567151] 
[45] Del Parigi A, Gautier JF, Chen K, et al. Neuroimaging and obesity: mapping the brain responses to hunger and satiation in humans using positron emission tomography. Ann NY Acad Sci 2002; 967: 389-97. [http://dx.doi.org/10.1111/j.1749-6632.2002.tb04294.x] [PMID: 12079866]

[46] De Silva A, Salem V, Matthews PM, Dhillo WS. The use of functional MRI to study appetite control in the CNS. Exp Diabetes Res 2012; 2012: 764017-23. [http://dx.doi.org/10.1155/2012/764017] [PMID: 22719753]

[47] Neary MT, Batterham RL. Gaining new insights into food reward with functional neuroimaging. Forum Nutr 2010; 63: 152-63. [http://dx.doi.org/10.1159/000264403] [PMID: 19955783]

[48] Rolls BJ, Rowe EA, Rolls ET, Kingston B, Megson A, Gunary R. Variety in a meal enhances food intake in man. Physiol Behav 1981; 26(2): $215-21$. [http://dx.doi.org/10.1016/0031-9384(81)90014-7] [PMID: 7232526]

[49] Raynor HA, Wing RR. Effect of limiting snack food variety across days on hedonics and consumption. Appetite 2006; 46(2): 168-76. [http://dx.doi.org/10.1016/j.appet.2005.12.001] [PMID: 16488056]

[50] Havermans RC, Janssen T, Giesen JC, Roefs A, Jansen A. Food liking, food wanting, and sensory-specific satiety. Appetite 2009; 52(1): 222-5. [http://dx.doi.org/10.1016/j.appet.2008.09.020] [PMID: 18951934]

[51] Mattes RD. Physiologic responses to sensory stimulation by food: nutritional implications. J Am Diet Assoc 1997; 97(4): 406-13. [http://dx.doi.org/10.1016/S0002-8223(97)00101-6] [PMID: 9120195]

[52] de Graaf C, Blom WA, Smeets PA, Stafleu A, Hendriks HF. Biomarkers of satiation and satiety. Am J Clin Nutr 2004; 79(6): 946-61. [PMID: 15159223]

[53] Baynes KC, Dhillo WS, Bloom SR. Regulation of food intake by gastrointestinal hormones. Curr Opin Gastroenterol 2006; $22(6)$ : 626-31. [http://dx.doi.org/10.1097/01.mog.0000245537.43142.63] [PMID: 17053440]

[54] Cummings DE. Ghrelin and the short and long-term regulation of appetite and body weight. Physiol Behav 2006; 89(1): 71-84. [http://dx.doi.org/10.1016/j.physbeh.2006.05.022] [PMID: 16859720]

[55] De Vriese C, Delporte C. Influence of ghrelin on food intake and energy homeostasis. Curr Opin Clin Nutr Metab Care 2007; 10(5): 615-9. [http://dx.doi.org/10.1097/MCO.0b013e32829fb37c] [PMID: 17693746]

[56] le Roux CW, Patterson M, Vincent RP, Hunt C, Ghatei MA, Bloom SR. Postprandial plasma ghrelin is suppressed proportional to meal calorie content in normal-weight but not obese subjects. J Clin Endocrinol Metab 2005; 90(2): 1068-71. [http://dx.doi.org/10.1210/jc.2004-1216] [PMID: 15522935]

[57] Batterham RL, Cohen MA, Ellis SM, et al. Inhibition of food intake in obese subjects by peptide YY3-36. N Engl J Med 2003; 349(10): 941-8. [http://dx.doi.org/10.1056/NEJMoa030204] [PMID: 12954742]

[58] Araya H, Contreras P, Alviña M, Vera G, Pak N. A comparison between an in vitro method to determine carbohydrate digestion rate and the glycemic response in young men. Eur J Clin Nutr 2002; 56(8): 735-9. [http://dx.doi.org/10.1038/sj.ejcn.1601386] [PMID: 12122549]

[59] Ludwig DS. Dietary glycemic index and obesity. J Nutr 2000; 130(2S)(Suppl.): 280S-3S. [PMID: 10721888]

[60] Holt S, Brand J, Soveny C, Hansky J. Relationship of satiety to postprandial glycaemic, insulin and cholecystokinin responses. Appetite 1992; 18(2): 129-41. [http://dx.doi.org/10.1016/0195-6663(92)90190-H] [PMID: 1610161]

[61] Roberts SB. High-glycemic index foods, hunger, and obesity: is there a connection? Nutr Rev 2000; 58(6): $163-9$. [http://dx.doi.org/10.1111/j.1753-4887.2000.tb01855.x] [PMID: 10885323]

[62] Augustin LS, Franceschi S, Jenkins DJ, Kendall CW, La Vecchia C. Glycemic index in chronic disease: a review. Eur J Clin Nutr 2002; 56(11): 1049-71. [http://dx.doi.org/10.1038/sj.ejcn.1601454] [PMID: 12428171]

[63] Bao J, de Jong V, Atkinson F, Petocz P, Brand-Miller JC. Food insulin index: physiologic basis for predicting insulin demand evoked by composite meals. Am J Clin Nutr 2009; 90(4): 986-92.

[http://dx.doi.org/10.3945/ajcn.2009.27720] [PMID: 19710196]

[64] Nimptsch K, Brand-Miller JC, Franz M, Sampson L, Willett WC, Giovannucci E. Dietary insulin index and insulin load in relation to biomarkers of glycemic control, plasma lipids, and inflammation markers. Am J Clin Nutr 2011; 94(1): $182-90$. [http://dx.doi.org/10.3945/ajcn.110.009555] [PMID: 21543531]

[65] Foster-Powell K, Holt SH, Brand-Miller JC. International table of glycemic index and glycemic load values: 2002. Am J Clin Nutr 2002; 76(1): 5-56. [PMID: 12081815]

[66] Wolever TM, Vorster HH, Björck I, et al. Determination of the glycaemic index of foods: interlaboratory study. Eur J Clin Nutr 2003; 57(3): 475-82. 
[http://dx.doi.org/10.1038/sj.ejcn.1601551] [PMID: 12627186]

[67] Björck I, Nyman M, Pedersen B, Siljeström M, Asp N, Eggum BO. On the digestibility of starch in wheat bread - studies in vitro and in vivo. J Cereal Sci 1986; 4: 1-11.

[http://dx.doi.org/10.1016/S0733-5210(86)80002-9]

[68] Englyst KN, Vinoy S, Englyst HN, Lang V. Glycaemic index of cereal products explained by their content of rapidly and slowly available glucose. Br J Nutr 2003; 89(3): 329-40. [http://dx.doi.org/10.1079/BJN2002786] [PMID: 12628028]

[69] Anderson GH, Moore SE. Dietary proteins in the regulation of food intake and body weight in humans. J Nutr 2004; 134(4): 974S-9S. [PMID: 15051857]

[70] Morrison CD, Reed SD, Henagan TM. Homeostatic regulation of protein intake: in search of a mechanism. Am J Physiol Regul Integr Comp Physiol 2012; 302(8): R917-28 [http://dx.doi.org/10.1152/ajpregu.00609.2011] [PMID: 22319049]

[71] Halton TL, Hu FB. The effects of high protein diets on thermogenesis, satiety and weight loss: a critical review. J Am Coll Nutr 2004; 23(5): $373-85$. [http://dx.doi.org/10.1080/07315724.2004.10719381] [PMID: 15466943]

[72] Reganda A, Chowdhuryb Z, Tosha SM, Wolever T, Wooda P. The molecular weight, solubility and viscosity of oat beta-glucan affect human glycemic response by modifying starch digestibility. Food Chem 2011; 129: 297-304. [http://dx.doi.org/10.1016/j.foodchem.2011.04.053]

[73] Tiwari U, Cummins E. Meta-analysis of the effect of $\beta$-glucan intake on blood cholesterol and glucose levels. Nutrition 2011; 27(10): 1008-16. [http://dx.doi.org/10.1016/j.nut.2010.11.006] [PMID: 21470820]

[74] Lyly M, Ohls N, Lähteenmäki L, et al. The effect of fibre amount, energy level and viscosity of beverages containing oat fibre supplement on perceived satiety. Food Nutr Res 2010; 54: 54-8. [http://dx.doi.org/10.3402/fnr.v54i0.2149] [PMID: 20401343]

[75] Beck EJ, Tosh SM, Batterham MJ, Tapsell LC, Huang XF. Oat beta-glucan increases postprandial cholecystokinin levels, decreases insulin response and extends subjective satiety in overweight subjects. Mol Nutr Food Res 2009; 53(10): 1343-51. [http://dx.doi.org/10.1002/mnfr.200800343] [PMID: 19753601]

[76] Beck EJ, Tapsell LC, Batterham MJ, Tosh SM, Huang XF. Oat $\beta$-glucan supplementation does not enhance the effectiveness of an energyrestricted diet in overweight women. Br J Nutr 2010; 103(8): 1212-22. [PMID: 19930764]

[77] Izydorczyk MS, Dexter JE. Barley $\beta$-glucans and arabinoxylans: Molecular structure, physicochemical properties, and uses in food products-a Review. Food Res Int 2008; 41: 850-68.

[http://dx.doi.org/10.1016/j.foodres.2008.04.001]

[78] Pins JJ, Kaur H. A review of the effects of barley b-glucan on cardiovascular and diabetic risk. CFW Res 2006; 51: 8-11.

[79] Schroeder N, Gallaher DD, Arndt EA, Marquart L. Influence of whole grain barley, whole grain wheat, and refined rice-based foods on shortterm satiety and energy intake. Appetite 2009; 53(3): 363-9. [http://dx.doi.org/10.1016/j.appet.2009.07.019] [PMID: 19643157]

[80] Wood PJ. Cereal b-glucan in diet and health. J Cereal Sci 2007; 46: 230-8. [http://dx.doi.org/10.1016/j.jcs.2007.06.012]

[81] Casiraghi MC, Garsetti M, Testolin G, Brighenti F. Post-prandial responses to cereal products enriched with barley $\beta$-glucan. J Am Coll Nutr 2006; 25(4): 313-20. [http://dx.doi.org/10.1080/07315724.2006.10719541] [PMID: 16943453]

[82] Vitaglione P, Lumaga RB, Montagnese C, Messia MC, Marconi E, Scalfi L. Satiating effect of a barley beta-glucan-enriched snack. J Am Coll Nutr 2010; 29(2): 113-21.

[http://dx.doi.org/10.1080/07315724.2010.10719824] [PMID: 20679146]

[83] Liljeberg H, Björck I. Bioavailability of starch in bread products. Postprandial glucose and insulin responses in healthy subjects and in vitro resistant starch content. Eur J Clin Nutr 1994; 48(3): 151-63. [PMID: 8194500]

[84] Hallström E, Sestili F, Lafiandra D, Björck I, Ostman E. A novel wheat variety with elevated content of amylose increases resistant starch formation and may beneficially influence glycaemia in healthy subjects. Food Nutr Res 2011; 55. [http://dx.doi.org/10.3402/fnr.v55i0.7074] [PMID: 21876685]

[85] Aravind N, Sissons M, Fellows CM, Blazek J, Gilbert EP. Optimisation of resistant starch II and III levels in durum wheat pasta to reduce in vitro digestibility while maintaining processing and sensory characteristics. Food Chem 2013; 136(2): 1100-9. [http://dx.doi.org/10.1016/j.foodchem.2012.08.035] [PMID: 23122168]

[86] Casiraghi MC, Pagani MA, Erba D, Marti A, Cecchini C, D’Egidio MG. Quality and nutritional properties of pasta products enriched with immature wheat grain. Int J Food Sci Nutr 2013; 64(5): 544-50. [http://dx.doi.org/10.3109/09637486.2013.766152] [PMID: 23373796] 
[87] Chillo S, Ranawana DV, Pratt M, Henry CJ. Glycemic response and glycemic index of semolina spaghetti enriched with barley $\beta$-glucan. Appl Nutr Investig 2011; 27(6): 653-8

[88] Gelencser T, Gál V, Hódsági M, Salgó A. Evaluation of quality and digestibility characteristics of resistant starch-enriched pasta. Food Bioprocess Technol 2008; 1: 171-9.

[http://dx.doi.org/10.1007/s11947-007-0040-z]

[89] Araya H, Hills J, Alviña M, Vera G. Short-term satiety in preschool children: a comparison between high protein meal and a high complex carbohydrate meal. Int J Food Sci Nutr 2000; 51(2): 119-24. [http://dx.doi.org/10.1080/096374800100813] [PMID: 10953755]

[90] Westerterp-Plantenga MS, Lejeune MP. Protein intake and body-weight regulation. Appetite 2005; 45(2): $187-90$. [http://dx.doi.org/10.1016/j.appet.2005.02.005] [PMID: 15950318]

[91] Paddon-Jones D, Westman E, Mattes RD, Wolfe RR, Astrup A, Westerterp-Plantenga M. Protein, weight management, and satiety. Am J Clin Nutr 2008; 87(5): 1558S-61S. [PMID: 18469287]

[92] Acheson KJ, Blondel-Lubrano A, Oguey-Araymon S, et al. Protein choices targeting thermogenesis and metabolism. Am J Clin Nutr 2011; 93(3): 525-34.

[http://dx.doi.org/10.3945/ajen.110.005850] [PMID: 21228266]

[93] Veldhorst MA, Nieuwenhuizen AG, Hochstenbach-Waelen A, et al. Dose-dependent satiating effect of whey relative to casein or soy. Physiol Behav 2009; 96(4-5): 675-82. [http://dx.doi.org/10.1016/j.physbeh.2009.01.004] [PMID: 19385022]

[94] Anderson GH, Tecimer SN, Shah D, Zafar TA. Protein source, quantity, and time of consumption determine the effect of proteins on shortterm food intake in young men. J Nutr 2004; 134(11): 3011-5. [PMID: 15514267]

[95] Hall WL, Millward DJ, Long SJ, Morgan LM. Casein and whey exert different effects on plasma amino acid profiles, gastrointestinal hormone secretion and appetite. Br J Nutr 2003; 89(2): 239-48. [http://dx.doi.org/10.1079/BJN2002760] [PMID: 12575908]

[96] Akhavan T, Luhovyy BL, Brown PH, Cho CE, Anderson GH. Effect of premeal consumption of whey protein and its hydrolysate on food intake and postmeal glycemia and insulin responses in young adults. Am J Clin Nutr 2010; 91(4): 966-75. [http://dx.doi.org/10.3945/ajcn.2009.28406] [PMID: 20164320]

[97] Luhovyy BL, Akhavan T, Anderson GH. Whey proteins in the regulation of food intake and satiety. J Am Coll Nutr 2007; 26(6): 704S-12S. [http://dx.doi.org/10.1080/07315724.2007.10719651] [PMID: 18187437]

[98] Blundell J. Making claims: functional foods for managing appetite and weight. Nat Rev Endocrinol 2010; 6(1): 53-6. [http://dx.doi.org/10.1038/nrendo.2009.224] [PMID: 20010971]

(C) Alviña and Araya; Licensee Bentham Open

This is an open access article licensed under the terms of the Creative Commons Attribution-Non-Commercial 4.0 International Public License (CC BY-NC 4.0) (https://creativecommons.org/licenses/by-nc/4.0/legalcode), which permits unrestricted, non-commercial use, distribution and reproduction in any medium, provided the work is properly cited. 